\title{
Two books, two decades, two agendas: Cherryl Walker and Nomboniso Gasa's edited volumes on Women's History in South Africa
}

\section{Lato Frank Ntwape ${ }^{*}$ and Lize Kriel ${ }^{*}$}

\begin{abstract}
This article was prompted by the question of what had happened to women's history from 1990. At that time, according to an assessment by Bozzoli and Delius, it had not (yet) developed into a "recognisable separate field of scholarship in South Africa". The aim of this investigation is to explore the ways in which two collections of essays that appeared from 1990 onwards interpret the task of writing women's history: Women and Gender in Southern Africa to 1945, edited by Cherryl Walker and published in 1990 and Women in South African History, edited by Nomboniso Gasa and published in 2007. While these collections of essays are by no means the only post-1990 publications with a focus on women's and gender history, few others claim the same comprehensiveness in their titles. This study attempts to show how these two books functioned in the process of interpreting women's history and whether or not each contributed to configuring the remit and the subject of South African women's history and its status as a separate field. The agency (will power / instrumentality) required to produce and promote the books, the approaches taken in the two collections and the ways the former influenced the latter, will be investigated. This is done by tracing the reception of the two books in scholarly publications (with reference to book reviews as well as citations), and also by interviewing academics invested in the field.
\end{abstract}

Key words: Women's history; gender history; South African historiography; Cherryl Walker; Nomboniso Gasa; feminism.

* $\quad$ Lato Frank Ntwape is based in Rustenburg and is enrolled for his $\mathrm{PhD}$ in Curriculum Studies at the University of the North West. He holds an MA in History from the University of Pretoria, where his focus was on the historiography of women's history in South Africa as perceived by both local and international academics and activists. The research for this current article was conducted while enrolled as a student in the Department of Historical and Heritage Studies, University of Pretoria.

* $\quad$ Lize Kriel teaches Visual Cultures Studies in the Department of Visual Arts, University of Pretoria. In her research she pursues topics on the history of women, as well as histories of authorship, publishing and reading, mostly from missionary archives. Lato Ntwape's MA study was supervised by her, with Thula Simpson as co-supervisor. The current article is the result of further collaboration between Kriel and Ntwape based on Ntwape's MA study.

How to cite this article: L.F. Ntwape \& L. Kriel, "Two books, two decades, two agendas: Cherryl Walker and Nomboniso Gasa's edited volumes on Women's History in South Africa", Historia, 63, 1, May 2018, pp 150-177.

http://dx.doi.org/10.17159/2309-8392/2018/v63n1a8

Copyright: (CThe Author(s). Published under a Creative Commons Attribution Licence. 


\section{Opsomming}

Die vraag, wat sedert 1990 met vrouegeskiedenis gebeur het, het aanleiding gegee tot hierdie artikel. Teen daardie tyd, aldus die assessering van Bozzoli en Delius, het dit nog nie tot 'n "herkenbare afsonderlike veld van kundigheid in Suid-Afrika" ontwikkel nie. Die doel met hierdie ondersoek is om die maniere te verken waarop twee versamelings opstelle wat vanaf 1990 verskyn het, die taak om vrouegeskiedenis te skryf, sou interpreteer: Women and Gender in Southern Africa to 1945, saamgestel deur Cherryl Walker en gepubliseer in 1990 en Women in South African History, saamgestel deur Nomboniso Gasa en gepubliseer in 2007. Terwyl hierdie versamelings van opstelle hoegenaamd nie die enigstes met 'n fokus op vroue- en gendergeskiedenis was wat na 1990 geproduseer is nie, het weinig ander met hulle titels op dieselfde omvattendheid aanspraak gemaak. Hierdie studie poog om aan te dui hoe hierdie twee boeke gefunksioneer het in die proses om vrouegeskiedenis te interpreteer, en wat hulle bydrae was tot die daarstelling van die bestek en die vak van Suid-Afrikaanse vrouegeskiedenis - insluitend die status daarvan as 'n afsonderlike veld - al dan nie. Die agentskap (wilskrag / instrumentaliteit) benodig om die boeke te produseer en te bevorder, die benaderings gevolg in die twee versamelings en die manier waarop die een die ander beinvloed het, sal bestudeer word. Dit word gedoen deur die ontvangs van die twee boeke in wetenskaplike publikasies na te speur (met verwysing na boekresensies sowel as sitasies) en ook deur onderhoude gevoer met akademici wat in die veld onderlê is.

Sleutelwoorde: Vrouegeskiedenis; gendergeskiedenis; Suid-Afrikaanse historiografie; Cherryl Walker; Nomboniso Gasa; feminisme.

\section{Introduction}

In 1990, the year in which Nelson Mandela was released from prison and the transition towards the non-racial democratic elections of 1994 got under way, historians Belinda Bozzoli and Peter Delius took stock of radical history writing in South Africa. In their review they observed that women's history "has not come to constitute a significant or recognisable separate field of scholarship in South Africa". ${ }^{1}$ In an article published in 1992, Linzi Manicom observed a change in this situation. She based her assessment on an increase in the number of journal articles published on the history of South African women from 1990, as well as the introduction of women's studies programmes at some South African universities. ${ }^{2}$ She also referred to the publication in 1990 of the book Women and Gender in Southern Africa to 1945, edited by Cherryl Walker. The state of women's and gender history by 1990 was captured in this volume.

1. B. Bozzoli and P. Delius, "Radical History and South African Society", Radical History Review, XLVI-XLVII (1990), p 33; L. Manicom, "Ruling Relations, Rethinking State and Gender in South African History", Journal of African History, 33, 3 (1992), p 441.

2. Manicom, "Ruling Relations, Rethinking State and Gender", p 441. 
In 2007 another volume of chapters, this edited by Nomboniso Gasa was published under the title Women in South African History. By referring to the Walker volume, the new book simultaneously acknowledged the prominence Walker's 1990 collection had gained in the study of South African women's history, and announced its intention to supersede it as an assessment of the current state of the same field. These collections of essays were by no means the only ones with a focus on women's and gender history to be produced post-1990, but few others claimed the same comprehensiveness through their titles. ${ }^{3}$

Walker's collection was hailed by many reviewers as the first comprehensive collection that questioned a biased, male-dominated history that excluded women from southern African history. Most contributors were university-based academics and were expected to question patriarchal tendencies as expounded by colonists and often replicated by historians in their writing. Gasa's edited collection, on the other hand, came later, thirteen years into the new democratic South Africa. Notably it focused only on South Africa and not on the broader southern Africa. It featured contributions by university-based academics and also by activists affiliated to organisations and institutions other than universities. The authors were intent on reviewing earlier methodologies of writing women's history.

This article attempts to show how these two comprehensive books functioned in the processes of interpreting women's history. The agency (power to bring change/ instrumentality) required to produce and promote the books, the approaches taken in the two collections, will be investigated. This is done by tracing the way these two books were received as evidenced in scholarly publications, and also by conducting interviews with interested academics. ${ }^{4}$

Different definitions have surfaced to determine what gender, feminist and women's history are. In the South African context, women's history was often conflated with gender history. This is probably because mainstream historical writing in South Africa has for a long time ignored women's history. Males dominated history and their activities were more visible that women's. In South Africa, the founding members of the African National Congress (initially named the South African National Native Congress) were all male; the underground struggle against apartheid was mostly associated with men; the Broederbond was an organisation for white Afrikaner men, the Black Consciousness Movement (BCM) was mainly influenced by males, etc. Therefore, women's history and its definitions were significantly subdued.

3. A collection of essays with a more specific focus, which appeared between the Walker and Gasa volumes, was W. Woodard, P. Hayes and G. Minkley (eds), Deep Histories. Gender and Colonialism in Southern Africa (Brill, Leiden, 2002).

4. To counter the notion of the "timelessness" and the "inherent" truth value of historical knowledge, and in an attempt to emphasise how it has been constructed over time, wherever appropriate this chapter is written in the past tense; utterances and statements by historians are reported and linked to the dates on which they were published. 
Gender historians investigated the past roles, influences and experiences of men and women respectively; they sought to discover sex roles and symbolisms across periods and societies. ${ }^{5}$ This cannot claim to stand for women's history per se, because men are pitted against women. And yet the assumption that gender history reflects the correction of male domination over the recognition of women, persists. Women's history refers to women's experiences, activities and discourses, ${ }^{6}$ and proclaims women as valid historical subjects. ${ }^{7}$ Feminism, on the other hand, insists on the total release of women from male domination. It moves from the premise that subordination of women in every society is problematic, ${ }^{8}$ and therefore women's history has to be made visible. ${ }^{9}$ Judith Bennett submitted that women's history was defined as historical work on women and feminist history as historical work that was infused by a concern about the past and present oppression of women. ${ }^{10}$ The aim of feminist historians was and still is to expose the unequal construction of gender roles. ${ }^{11}$ While the pursuit of women's history is not incompatible with a feminist agenda, historians and commentators who wish to use women's history interchangeably with gender history, pose a challenge to women's history when in the process women's experiences are captured elsewhere, outside the mainstream history, as an add-on.

For South African history, Deborah Gaitskell has argued that women's history should be a prerequisite to gender history; that we first need to understand what women were doing and how they experienced their lives before we move on to gender history. ${ }^{12}$ By glibly equating women's history to gender history, it was negated to a secondary position within history as a discipline. As for the practice of history more broadly in the international arena, in an article published in 1989, Bennett cautioned against complacency:

... we seek to integrate women's experiences into mainstream history, to hire more women faculty, to create curricula that serve the needs of female as well as male students, and to improve the status of women on our campuses. These are important, indeed crucial issues, and they rightly absorb the attention and energy of many feminist scholars. But they are not sufficient. As feminist academics, we must have two agendas: first, to eradicate the misogynistic traditions of academia

5. J.W. Scott, "Gender: A Useful Category of Historical Analysis", American Historical Association, 91, 5 (December 1986), p 1054.

6. P.T. Zeleza, Manufacturing African Studies and Crises (Codesria, Dakar, 1997), p 182.

7. Scott, “Gender: "A Useful Category of Historical Analysis", p 1056.

8. C. Walker, Women and Resistance in South Africa (David Philip, Cape Town, 1991), p xxiii.

9. G. Duganzich, “She's who Make History: Reviewing the Historical Treatment of Black Women by Four South African Scholars", Historia, 44, 1 (1999), p 68.

10. J. Bennett, "Feminism and History", Gender \& History, 1, 3 (1989), p 253.

11. L.F. Ntwape, “A Historiography of South African Women's History from c. 1990. A Survey of Monographs, Anthologies and Journal Articles", MA dissertation, University of Pretoria, 2015, p 6.

12. N. Erlank and L. Clowes, "Reports on Colloquium Sessions, Session 7: Writing and Teaching Gendered History in Africa in the Twenty-first Century", South African Historical Journal, 50 (2004), p 232. 
in its many, entrenched forms, and second, to contribute - through our privileged position as educated people, as research scholars, as teachers - to the understanding of (and hence, final eradication of) women's oppression. ${ }^{13}$

It is against this backdrop that we argue in this essay that the two texts we are about to unpack below have made a huge statement trying to convince historians that women's history needs the attention it deserves within historical texts. Mainstream historical writing has for a long time ignored women's history. ${ }^{14}$ This point was sustained by Manicom when she argued that:

The further development of women's history in South Africa cannot therefore ensure either that it will be more valorized as a field of research or that it will be taken into account within mainstream history. Nor can it be assumed that the production of a "critical mass" of feminist and women's history will prompt a more profound, gendered re-thinking of the historical enterprise. Such an outcome is dependent both on the institutional politics around the legitimacy of gender inquiry in what is now recognized as "history" (including all its subdisciplines) and on the way in which gender analysis is conceived by South Africanist historians. ${ }^{15}$

Mainstream historical writing in South Africa has largely ignored women's history. As John Tosh put it, with reference to the international arena:

One of the problems of women's history has been that so much of its output has concerned areas like family, philanthropy and feminist politics which can be shrugged off by mainstream historians as a minority pursuit with no bearing on their work (they are of course mistaken). ${ }^{16}$

This situation is frustrating for proponents and practitioners of women's history, but also motivated the fight for the recognition and reclamation of important strands for women. The following renowned works on South African history that were commonly used over the past decades suffer from a neglect of women's history. They include Monica Wilson and Leonard Thompson's A History of South Africa to 1870 (1982); Paul Maylam's A History of the African People of South Africa: From the Early Iron Age to the 1970s (1989); T.R.H. Davenport's South Africa, a Modern History (various editions since 1987); B.J. Liebenberg and S.B. Spies's co-written South Africa in the 20th Century (1993); Robert Ross's A Concise History of South Africa (1999); Leonard Thompson's A History of South Africa (2006); Hermann Giliomee's The Afrikaners. A Biography of a People (2003); William Beinart's Twentieth Century South Africa (1994) and Herman Giliomee and Bernard Mbenga's New History of South Africa (2007). Notwithstanding the fact that these books have been widely and excellently reviewed, they all tended to provide little visibility to women. Where women were mentioned, it was in relation to political struggle and only to a limited extent. For his

13. Bennett, "Feminism and History", p 256.

14. Ntwape, "A Historiography of South African Women's History", p 70.

15. Manicom, "Ruling Relations, Rethinking State and Gender", p 443.

16. J. Tosh, "What Should Historians Do with Masculinity? Reflections on Nineteenth Century Britain”, History Workshop, 8 (1994), p 179. 
part, Hermann Gilliomee attempted to capture the history of women's roles in the Great Trek and other epic events in Afrikaner history. However, women's agency was not addressed. What white women did to challenge the volksmoeder ideology is not uncovered. Basically, as Manicom put it:

Historians doing "general" or "universal" history continue to ignore gender. With some women seen to be doing the work of gender history within a designated sub-field, other (particularly) male historians can rationalize an exemption from the struggle to integrate a gender perspective into their work - a challenge that grows ever more sophisticated and consequential as feminist theory advances as one that potentially can undermine their mastery of the subject. ${ }^{17}$

Cherryl Walker and Nomboniso Gasa are among the historians who have argued the case for women's history to be recognised. The following paragraphs will show how these two prominent books have featured in the process to bring women's history and agency to the fore, even though the general, mainstream historical writing struggled to recognise this as integral to history as a discipline.

\section{Women and Gender in Southern Africa to 1945}

The Walker publication was mainly influenced by the concerns expressed by Belinda Bozzoli in her famous 1983 essay, "Marxism, Feminism and South African Studies", in which she referred to the "patchwork quilt of patriarchies"18 to explain the diversity of gender oppression in the nineteenth-century southern African landscape. Mapping a new path for the interpretation of women's history, Bozzoli's article became the foundation for most subsequent writings in women's history in South Africa to date. It was a model for women's history within academic and activist circles. It questioned the interpretations of South African women's history from the nineteenth to the twentieth century. This pervasive reversal was a move to trace and articulate women's role in the ordering and disordering of South African society over time. Bozzoli's eloquent appeal resonated in feminist history in the 1970s and 1980s a time when women debated contours to address the interstices that undermined women's history in South Africa.

Walker gave recognition to Bozzoli's inspiration on the first page of her overview chapter which introduced Women and Gender in Southern Africa to 1945. The book was jointly published by David Philip in Cape Town and James Currey in London. From Walker's notes of thanks in the preface, it was clear that the book benefited from transnational scholarly collaboration. Not only was the University of the Witwatersrand-based sociologist and fellow contributor to the book, Jacklyn Cock, lauded for her support, but so too was Stanford University's Centre for Research on

17. Manicom, "Ruling Relations, Rethinking State and Gender, p 442.

18. B. Bozzoli, "Marxism, Feminism and South African Studies", Journal of Southern African Studies, 9, 2 (1983), pp 139-171. 
Women (later the Institute for Research on Women and Gender), that was recognised for the support it gave Walker when she was an affiliated scholar in the mid-1980s. ${ }^{19}$

The aim of Walker's collection was to expose the responses and roles of women in the pre-capitalist societies right into the labour-intensive period. How women played a part in the formation of the economy and political landscape was central to this collection. On page four, Walker raised a number of questions that that she wanted to address on the intended impact of women's history in southern Africa. But most importantly, she explained that she wanted the book to address the historical gap that saw women's contribution being sidestepped by major historical writing. While women's history had received some attention prior to this publication, Walker's book aimed to give women's history an academic stature and bring into the equation that which had been ignored by mainstream history books at the time.

The book looked at how pre-capitalist society oppressed and exploited women, while Jeff Guy's presentation dealt more with explanation than resistance. Burman drew a picture of how colonial laws perpetuated the mistreatment and the undermining of women. "Women were regarded as perpetual minors and only in exceptional circumstances did a woman become the head of the family".20 The collection also outlined how colonial education subjugated women. Instead of emancipating them, it deepened patriarchal oppression. "Thus, education operated largely as the crucial agency of social control and cultural reproduction, defining and reinforcing certain social roles and initiating people into those skills and values which were essential for effective role performance". ${ }^{21}$

Furthermore, the colonial rulers continued the patriarchal domination through laws like Ordinance 50, thereby reinventing British patriarchy rather than bringing liberation to women in South Africa. This colonial domination extended to women of Indian descent too. We learn that in colonial Natal “... employers were able to benefit not only from female labour, which was very poorly remunerated if at all, but also from not having to bear the direct cost of introducing this labour supply."22 Here, women's agency was prevalent: they refused forced marriages and there were single women who moved from partner to partner for social and economic benefit. The arguments above indicate how authors began to unpack women's history during the colonial era. While they may not have shown women's agency (how they negotiated these terrains), the collection initiated a debate on a point that was ignored hitherto in mainstream historical writing.

19. C. Walker (ed.), Women and Gender in Southern Africa to 1945, (David Philip, Cape Town, 1990), Preface.

20. S. Burman, "Fighting a Two-Pronged Attack: The Changing Legal Status of Women in Cape-ruled Basotholand, 1872-1884", in Walker (ed.), Women and Gender, p 55.

21. J. Cock, "Domestic Service and Education for Domesticity: Incorporation of Xhosa Women into Colonial Society, in Walker (ed.), Women and Gender, p 95.

22. J. Beall, "Women under Indentured Labour in Colonial Natal, 1886-1911", in Walker (ed.), Women and Gender, p 152. 
The evaluation of Christianity and urbanisation in the book revealed the same pattern of patriarchal extension from Britain. Missionaries extended female "work" in a different and more attractive manner, yet the changes brought by missionaries failed to provide women with independence. For instance, while marriage was regulated, it did not remove male domination; instead, women were now controlled by colonial patriarchy. Christianity was intended to provide African women with a voice through education, to remove women from servitude by training them in sewing, cooking and cleaning, but this education was not meant to free the mind. It prepared the girls for marriage and Christian life. In her investigation of the relationship between domesticity and conversion to Christianity, Gaitskell managed to show agency. While the church affirmed male stereotyping, African women were able to contest their ascribed space. Irrespective of their literacy level, women were able to change the face of spirituality in the church and the conduct within unions. They made these more African and introduced their own style of preaching. ${ }^{23}$

Women and Gender in Southern Africa to 1945 does not always succeed in exposing and unearthing women's agency. For instance, while one appreciates the discussion on migrant labour and how this subsumed into family and marriage life in African societies, the author failed to trace women's agency overtly. Nevertheless, she should be commended that the notion of escape is discussed cautiously to indicate women's willingness to move away from oppressive encounters. This agency is clearly shown in the chapter by Phil Bonner, ${ }^{24}$ who discussed the activities women resorted to as survival strategies, such as beer brewing and prostitution, and how these were perceived as "misbehaviour", immoral and promiscuous in the eyes of the state and other patriarchal eyes; rather than as a sign that women did not want to be controlled.

The Walker collection closed with a look at ways in which white women were conceptualised and actualised. Elsabe Brink's presentation on the volksmoeder is an analysis of how women's history and women's position were used by prominent Afrikaner nationalists to advance Afrikaner culture, but she did not include an analysis of Afrikaner women's agency. In contrast, Linda Chisholm ${ }^{25}$ investigated how any deviance among white girls was interpreted as degeneracy. White girls were criminalised for transgressing not only the rules of socially acceptable feminine behaviour, but also those regulating relations between black and white. ${ }^{26}$ The chapter showed how young girls were controlled by the state, but Chisholm did not present their resistance as a form of agency. Walker concluded the volume by submitting that the fight for women's enfranchisement was a whites-only issue prior to 1930. In the absence of their own women's organisation, the ANC fought for African women, while the Women's Enfranchisement Association of the Union (WEAU) fought for the rights

23. D. Gaitskell, "Devout Domesticity? A Century of African Women's Christianity in South Africa, in Walker (ed.), Women and Gender, pp 251-272.

24. At the time, an associate professor at the University of Witwatersrand.

25. With the Department of Education at the University of the Witwatersrand.

26. L. Chisholm, "Gender and Deviance in South African Industrial Schools and Reformatories for Girls, 1911-1934", in Walker (ed.), Women and Gender, p 306. 
of white women. Thus, this "suffrage movement vehemently confirmed the roles of women as nurturers of children and enforcers of morality". ${ }^{27}$

\section{Reviews of Women and Gender in Southern Africa to 1945}

The Walker collection was widely reviewed by both local and international academics. As the first comprehensive book of essays on women's history in South Africa, it invoked many to recognise women's history. The early reviews in South African journals ascribed a watershed quality to the book. Lynda Gilfillan wrote a review for the literature studies-oriented journal Current Writing (1990). Somewhat contrary to our own assessment in the above outline of the book, she argued that the contributing authors were working towards a more transformed history by foregrounding women's agency in saying: “Women's agency is hereby posited as an alternative to the prevailing stereotype of the passive victim woman; moreover, power itself is perceived as being not entirely monolithic."28

While Marrion Wallace and Christine Sylvester appreciated the collection respectively as "an excellent set of contributions" 29 and an "admirable and intriguing feminist-minded volume", 30 Wallace pointed to the fact that the collection was "strongly influenced by relying on evidence drawn from white and/or male sources". ${ }^{31}$ They questioned the lack of interpretation of women's actions in several essays and noted some ambiguity in the introduction. They also wondered whether the collection addressed both racial and gender oppression of women. Margo Russel had some criticism, arguing that most chapters had not met the aims of the book as set out by Walker in her introduction, and added that the collection was composed of discrete descriptive chapters that lacked "theoretical signposts". 32 She was also somewhat critical that in some chapters secondary sources were consulted while primary sources were readily available,33 and remarked that a historical gap could not be filled by disregarding conventions of historical scholarship. She noted with concern what she referred to as the use of jargon and contradictions and misinformation by some of the contributors. ${ }^{34}$ In her review of the Walker publication, Jane Carruthers remarked on what she described as a lack of cohesion

27. Ntwape, "A Historiography of South African Women's History", p 44.

28. L. Gilfillan, "Review of Women and Gender in Southern Africa to 1945, edited by Cherryl Walker", Current Writing, 2, 1 (1990), p 175.

29. M. Wallace, "Review of Women and Gender in Southern Africa to 1945, edited by Cherryl Walker", The International Journal of African Historical Studies, 24, 3 (1991), p 657.

30. C. Sylvester, "Review of Women and Gender in Southern Africa to 1945, edited by Cherryl Walker", Journal of Southern African Studies, 17, 1 (March 1991), p 165.

31. Wallace, "Review of Women and Gender, p 656.

32. M. Russel, "Review of C. Walker (ed.), Women and Gender in Southern Africa to 1945", African Affairs, 91, 363 (1992), p 313.

33. Russel, "Review of C. Walker (ed.), Women and Gender in Southern Africa to 1945", p 313.

34. See Russel, "Review of C. Walker (ed.), Women and Gender in Southern Africa to 1945", p 314, for a better understanding of this criticism. 
and focus and expressed the hope that in a future publication Cherryl Walker would explore the changing relationships between men and women in more detail. ${ }^{35}$

Nevertheless, the collection also received huge accolades locally and internationally. Ros Posel, Adeline Korb, Shula Marks and Marc Epprecht, among others, praised the collection. It was credited with elevating gender to a mandatory category of historical analysis, giving historians a worthy touchstone for the future. ${ }^{36}$ It was argued that the methodology employed and the objective, scientific presentation of facts made it a good reference work, ${ }^{37}$ and that it offered a powerfully argued overview which not only managed to place all the essays in context and relate them to one another, but also brought out the major themes and suggested some remaining ones for further research. ${ }^{38}$ Epprecht mentioned the Walker compilation's indebtedness to Bozzoli's earlier work: "In essence, Walker has put together the first comprehensive response to Bozzoli's challenge to develop the empirical base for a gendered history of South Africa," ${ }^{39}$ while Femi Ojo-Ade, credited Walker with:

... the dexterity of a surgeon to expose and then bring together the essential features of each study in a remarkable analytical-synthetic exercise that can only be applauded, not least because it will make many wish to read the whole book from cover to cover. ${ }^{40}$

Paula M. Krebs argued that the collection dealt with women's exposure to foreign administrative controls and laws that were meant to oppress them, ${ }^{41}$ although she noted with concern the absence of black contributors, while observing that as many as three chapters were dealing with white women in South Africa. Gay W. Siedman's assessment put some of Krebs' observations into perspective: "Rather than describing women's organized resistance, as much previous feminist

35. J. Carruthers, "Review of C. Walker (ed.), Women and Gender in Southern Africa to 1945”, Kleio, 23 (1991), p 115.

36. R. Posel, "Review of Women and Gender in Southern Africa to 1945, edited by C. Walker", South African Historical Journal, 25, 2 (1990), pp 263-264.

37. A. Korb, "Review of Women and Gender in Southern Africa to 1945, edited by C. Walker", South African Journal for Cultural History, 5, 1 (1990), p 32.

38. S. Marks, "Review of Women and Gender in Southern Africa to 1945 edited by Cherryl Walker", Agenda, 9 (1991), p 83.

39. M. Epprecht, "Review of Women and Gender in Southern Africa to 1945, edited by Cherryl Walker; and Women of Phokeng: Consciousness, Life Strategy and Migrancy in South Africa, 1900-1993 by B. Bozzoli and M. Nkotsoe", The International Journal of African Historical Studies, 25, 2 (1992), p 401.

40. F. Ojo-Ade, "Review of Women and Gender in Southern Africa to 1945, edited by Cherryl Walker; and Mothers of the Revolution: The War Experiences of Thirty Zimbabwean Women, by I. Staunton", The Journal of Modern African Studies, 30, 4 (1992), p 693.

41. P.M. Krebs, "Review of Women and Gender in Southern Africa to 1945, edited by Cherryl Walker", Victorian Studies, 36, 1 (Autumn 1992), p 89. 
historiography in the region has done, the collection seeks to explain ... the pervasions of women's conservatism through South Africa history." 42

Women and Gender in Southern Africa to 1945 was not only reviewed in a wide range of journals, it also continued to be reviewed over a relatively extensive period of time. As from 1993, the reviews started affirming the deductions and conclusions of a number of previous reviewers. This is evident in the reviews by Jane L. Parpart of Dalhousie in the Canadian Journal of African Studies, ${ }^{43}$ as well as Donald Wilson's review in the 1994 issue of the Journal of the International African Institute. ${ }^{44}$ Looking back in 2007, Van der Spuy (then with Castleton State College) and Clowes (at the University of the Western Cape) acknowledged that this was the first comprehensive book of essays on women's history. However, they submitted that the focus of the collection was on the continuation of patriarchal oppression from pre-capitalist African societies to colonial societies. It was not concerned with agency, but with male domination: "... how oppression impacted on women, rather than how women acted on their own behalf". ${ }^{45}$ This indicated that the approach to this collection was not necessarily to show agency but rather to make women visible and discuss the oppression that women had faced from pre-capitalist times. The authors' intention was to bring women's history to the fore. As the first comprehensive collection by academics, it perhaps did not succeed in establishing a "recognised separate field of scholarship", but it did assert that social history was meant to talk about women's issues.

Their commentary on the volume's shortcomings aside, most reviewers concurred that the Walker collection had taken the debate on women's issues in South Africa to a higher level. Many reviewers singled out the chapters by Gaitskell and Bonner chapters as the most commendable contributions. But with hindsight it was also evident from the reviews and the analysis of the chapters that not all the aims as highlighted by Walker in the introduction were achieved. What is significant is that the collection sparked a lively and productive discourse, albeit in the absence of black historians. This is so because either way, history had to be written, irrespective of the colour of the historian. If it is biased, then it will be challenged; if there are gaps, then they will be filled by future historians. Two decades down the line, a number of those "future historians" were consulted, either in interviews, telphonically or by email, and asked how they perceived the Walker volume when looking back.

42. G.W. Siedman, "Review of The Comfort of Home: Prostitution in Colonial Nairobi, by Louise White; and Women and Gender in Southern Africa to 1945, edited by Cherryl Walker", Signs, Journal of Women and Culture in Society, 18, 3 (Spring 1993), p 710.

43. J.L. Parpart, "Review of Women and Gender in Southern Africa to 1945, edited by Cherryl Walker", Canadian Journal of African Studies, 28, 2 (1994), pp 378-379.

44. D. Wilson, "Review of Cherryl Walker, Women and Gender in Southern Africa to 1945", Journal of the International African Institute, 64, 3 (1994), p 444.

45. P. van der Spuy and L. Clowes, "Accidental Feminists? Recent Histories of South African Women”, Kronos, 33 (2007), p 214. 


\section{Reflections on Women and Gender in Southern Africa to 1945}

In hindsight, when the editor herself was asked about her book in 2013, she intimated that she did not see the book as a watershed, arguing that there had been many other important contributions previously. Rather, she believed that it "was a valuable collection in its time that brought together components of that body of work in an edited collection". ${ }^{46}$ Also looking back from 2013 as vantage point, Professor Deevia Bhana of the University of Natal School of Education concurred that while she did not believe it was a watershed publication, she posited that the "collection reflects a moment in history. Its value lay, however, in the fact that women's history in SA was and is neglected but this is not peculiar to South Africa and has a global order to it the neglect of women in history at a global scale". ${ }^{47}$

The Walker collection did indeed show that women's issues had been ignored for a long time, and ought to be brought forward. In 2013, the gender historian and at the time head of the History Department at the University of Johannesburg, Natasha Erlank, explained that prior to the publication of this book, scholars worked individually rather than interacting with others in the field. It was this collection, then, that brought them together, and encouraged them to begin discussing gender issues. ${ }^{48}$ Gender specialist Amanda Gouws, also agreed, in 2013, that the collection "is one of the first books to document women's history and make a contribution to political change in South Africa". ${ }^{49}$ She explained that after Women and Gender in Southern Africa to 1945, many contributors were able to focus on agency within women's history. While the collection concentrated mainly on the role played by women in the development of South African history, writers of women's history began to examine strategic and practical issues that had previously been neglected in general histories.

While the assessments of these and other South African scholars consulted were carefully weighed, the two north American scholars were more outspoken about the Walker book's position in the canon of South African gender and women's history. Denise Walsh, an associate professor in the Woodrow Wilson Department of Politics and Women, Gender and Sexuality, argued that "... there are many wonderful publications from a wide range of disciplines, including history, to choose from", and mentioned works such as that by Cornwall (2005) ${ }^{50}$. In Walshe's view, the "Walker collection stands out among them for its range across time, breadth of themes, and unique analytical insights". ${ }^{51}$ Hannah Britton, the director of the Center for the Study of Injustice at the Institute of Policy and Social Research at the University of Kansas, believed that:

46. C. Walker's response to an enquiry by L.F. Ntwape, 26 August 2013.

47. D. Bhala's response to an enquiry by L.F. Ntwape, 15 October 2013.

48. N. Erlank, interview conducted by L.F. Ntwape on 10 September 2013, via Skype.

49. A. Gouws, response to an enquiry by L.F. Ntwape, 12 November 2013.

50. Walsh refers to Andrea Cornwall's book, Readings in Gender in Africa (Indiana University Press, Bloomington, 2005).

51. D. Walsh, response to an enquiry by L.F. Ntwape, 13 February 2014. 
this work has been instrumental in having scholars and leaders recognise the role women played in history, politics, economics, and religion. It gave voice and visibility to a strong legacy of women's activism during a time when it was both unexpected and unseen. It is a work we all turn to, even today. Though there may be limitations when looking back at a work like this, it still should be celebrated for what it did for women's history for the first time and in a new and important way. 52

Thus, the fact of it being there, internationally circulated and known, and for the lack of its critics having produced a better alternative, the Walker volume has, over the years, outlived much of the early criticism expressed on its merits.

\section{Women in South African History}

The twenty-first century saw the production of another collection of women's history, which by its title alone, asserted its canonical potential. Women in South African History, was edited by Nomboniso Gasa (a political activist against apartheid, and researcher at the University of South Africa's Department of History) and was published by the South African Human Sciences Research Council (HSRC) in 2007. It included contributions from historians, feminists and activists. This collection proclaimed the hope to turn women's history around and show how women, symbolically, removed "boulders and cross[ed] rivers"; it challenged previous methodologies used to unpack women's history and its main theme was to show how women emancipated themselves from hardships in the midst of the triple oppression they faced as black women, mothers and workers.

Unlike Walker's collection, Gasa's edited volume, Women in South African History was not meant to close a historical gap. It was "... not a corrective effort to make women visible in history, to write women's history or to fill the gaps which are missing in various historical and social science works about women's place and location ... [but] ... to write of women's location, presence and experience in history". 53 The aim of the collection, according to Gasa, was to provide the reader with a quest for women's emancipation. ${ }^{54}$ The intention of the volume was to revisit how women's history has been written thus far and it included chapters from activists and academics. Contributors were charged with writing about the "women who cross rivers and surmount unimaginable challenges, the kind we prefer not to think about, these women who follow the flow of the Limpopo southwards - they too seek their emancipation". 55 The volume was intended to prove “... the importance of recognising women's multiple and varied experiences and identities, and [assist] with building a feminist theoretical, conceptual and ideological response that is centred on this". ${ }^{56}$ As Walker admitted of her book, Gasa also acknowledged that this volume was not

52. H. Britton, response to an enquiry by L.F. Ntwape, 30 January 2014.

53. N. Gasa (ed.), Women in South African History: Basus'iimbokodo, bawel'imilambo/They Remove Boulders and Cross Rivers (HSRC Press, Cape Town, 2007), p xviii.

54. Gasa (ed.), Women in South African History, p xv.

55. Gasa (ed.), Women in South African History, p xv.

56. Gasa (ed.), Women in South African History, p xviii. 
exhaustive and points out that some themes, for example on the role of Indian women, women in the PAC and those in other political organisations, have not been addressed.

It should also be noted that unlike the Walker book which was an academic project published by independent publishers, Gasa's volume was a government project, commissioned and funded by the Department of Arts and Culture and published by the HSRC in Pretoria. The "Age of Hope through Struggle to Freedom" logo of the 50th anniversary of the Women's March to the Union Buildings in 1957 hence the song reference about moving boulders - is also displayed on the cover. The racial diversity of the contributors and the dual academic/nation-building approach to the book projected the intellectual image of the new democratic South Africa led by the former liberation movement now the ruling political party. Positioning itself on the cover page as a "transdisciplinary combination of seasoned and new voices" it aspired to mark a new turning point in the writing about women's history in the country.

In Gasa's book many of the authors examined the role of women and their agency in important historical events. Unlike most historical texts where women are portrayed as secondary citizens, here the authors showed what women did to challenge fixity. The collection also looked at women's role in pre-capitalist South Africa, in that there are, respectively, chapters by Jennifer Weir, ${ }^{57}$ Pumla Gqola, ${ }^{58}$ Helen Bradford ${ }^{59}$ and Elizabeth van Heyningen 60 that investigated chiefly women and leadership; the voices of slave women; narratives that interpreted the Nonqawuse story, and women in the South African War. Weir challenged patriarchal kingship by purporting that "women leadership took a variety of forms, sometimes in the military, but more often economic and religious". ${ }^{61}$ Powerful women like Queen Manthatise and Machibise were often involved in "men's roles" such as military combat and successfully engaged in expeditions against male leaders and used their positions to take control; they were not passive victims as previously recorded, and this showed women's agency.

Gqola postulated that the penultimate agency by slave women was deliberately constructed as primitive conduct and suggested that "such moves reduce successful resistance through flight into evidence of the innate inferiority of the

57. Member of staff in the Teaching and Learning Centre, Murdoch University, Australia.

58. Pumla Gqola holds a PhD from University of Munich with a thesis on slavery and the South African post-apartheid imagination. At the time of writing she headed Open Speak at the Meraka Institute and is an Extraordinary Associate Professor at UWC.

59. Bradford specialised in topics on war, labour, literature, photography, reproductive politics and millenarianism in a colonial context,

60. Van Heyningen is a social historian, especially the social history of medicine. She concludes this section with a study on the South African War.

61. J. Weir, "Chiefly Women and Women's Leadership in Pre-colonial Southern Africa: 'Like three tongues in one mouth'”, in Gasa (ed.), Women in South African History, p 4. 
Khoe/San and other slaves". ${ }^{2}$ She argued that there have been a plethora of views on slave women expressed by settlers and historians alike, but frequently this related to other themes in history, not exclusively to the views of enslaved women. The rereading of slave women, she argued, had to concentrate on making them more visible and looking at their influence. ${ }^{63}$ The same applies to how Boer women fought against British doctors' ill-treatment in the concentration camps. This led to the formation of the Ladies Commission to investigate women's conditions in the camps, giving voices to British women who were loyalists. ${ }^{64}$ However, Van Heyningen failed to show how the Boer women withstood the ill-treatment.

Most narratives on Nonqawuse are male biased, ranging from a Xhosa perspective that Nonqawuse was a mistaken birth; then an accusation that she had been used by the imperial government to destroy Xhosa society; and finally, to an interpretation of the Nonqawuse dilemma as a childlike act of madness. All these are challenged and put into perspective by Helen Bradford. Bradford submitted that this historical event was a protest by women against male domination that weakened the patriarchal system. Historical texts accused Xhosa women of causing the disaster, while in effect, Nonqawuse's actions were proof of women's agency. They were not just events caused by a woman; they had begun long before Nonqawuse was born.

Nomboniso Gasa called for the reinterpretation and re-evaluation of women's history to decode the actual role of women in South African politics and in the shaping of South Africa. She criticised the approach to women's history used by Cherryl Walker and Julia Wells'65 as reactionary, arguing that it should instead have recorded women's political trajectory; that women's refusal to carry passes and pay fines, for example, should have been presented as ways in which women raised their opinions and challenged the oppression facing them. Gasa acknowledged that Walker's contribution opened new debates, but furthermore aligned herself with Frene Ginwala's voice of 1990, when Ginwala opined that the "... complexity of African women's political struggle calls for an approach that examines the spaces inbetween; the vast grey areas which are rich and complex with women's real experience must be explored fully".66 While acknowledging the limitations placed on them during the 1950s, she maintained that women defied oppression and created nuances that showed their strength. She rebuked the historiography in that it failed to unearth women's agency, which accepted that women were functional within the male wing and hence were silent and guided solely by nationalist thinking.

62. P.D. Gqola, "Tracing the Elusive Lives of Slave Women in (Slavocratic) South Africa", in Gasa (ed.), Women in South African History, p 24.

63. Gasa (ed.), Women in South African History, p 32.

64. E. van Heyningen, "Women and Gender in the South African War, 1899-1902", in Gasa (ed.), Women in South African History, p. 113.

65. Gasa was referring to Walker's book, Women and Resistance in South Africa (1991) and to Julia Wells, in her work We now Demand! The History of Women's Resistance to Pass Laws in South Africa (Wits University Press, Johannesburg, 1993).

66. N. Gasa, "'Let them Build More Goals'”, in Gasa (ed.), Women in South African History, p 145. 
Gasa argued that the 1950s provided a shift in women's activities when women within the ANC organised their march without the full blessing of the leadership. This march brought together women from different races and ideological backgrounds and social strata ${ }^{67}$ and stalled the provision of passes to women (as Wells also submitted in her work of 1993). By deploying women leaders in the march, women's movements contributed to a more vital, inclusive political process. ${ }^{68}$ This was so because even in the grip of a repressive government, women were still able to organise a significant event. Gasa concluded that the women's march should not be seen in the context of national liberation, but as a struggle for the public domain. ${ }^{69}$ This was an important assertion considering that the book she was editing was meant to mark the fiftieth commemoration of the march.

Luli Callinicos ${ }^{70}$ argued that part of the reason for the paucity of women's history was that feminist and general histories tended to provide narratives that made assumptions about women's experiences. ${ }^{71}$ She argued that women did not depend solely on men; they contested their working space and challenged previously male dominated terrains like political activism. "Some women decided to be more answerable to themselves for their decision and direction". ${ }^{72}$ This notion is developed further by Iris Berger ${ }^{73}$ who submitted that women challenged inequalities at the workplace. For Berger, the fact that the 1931 and 1932 strikes were led by women challenged and transcended white society's perception about women as the perpetual shadows of their husbands and the church. Women's role in trade unionism, she maintained, “... changed women's personal and collective identities, helping to shape the contours of a later South African feminist agenda" ${ }^{74}$

Raymond Suttner ${ }^{75}$ on the other hand, used archival material and oral interviews to investigate the role of women in the ANC-led underground. His chapter showed that women were key in the underground movement. They were not passive, but operated on dangerous missions within and outside the country. He also showed that the role of women "... needs to be understood as entailing a number of components, including planning, reconnaissance and a variety of other forms of

67. N. Gasa, "Feminisms, Motherisms, Patriarchies and Women's Voices in the 1950s", in Gasa (ed.), Women in South African History, p 220.

68. Wells, We Now Demand! p 140.

69. Gasa, "Feminisms, Motherisms, Patriarchies", p 214.

70. A social historian and heritage expert; at the time chairperson of the National Heritage Council.

71. Callinicos used her interviews with Martha Msomi and Thoko Virginia Mngoma to show how women defied what was expected of domestic workers by joining the ANC and campaigning for the organisation in the midst of apartheid laws.

72. L. Callinicos, "Testimonies and Transitions: Women Negotiating the Rural and Urban in the mid-20th Century", in Gasa (ed.), Women in South African History, p 116.

73. A feminist scholar and activist and chair of the History Department at the University of Albany, State University of New York.

74. I. Berger, "Generations of Struggle: Trade Unionism and the Roots of Feminism, 19301936", in Gasa (ed), Women in South African History, p 204.

75. At the time a research fellow in the History Department at Unisa. 
preparations". ${ }^{76}$ For her part, Jacklyn Cock $^{77}$ analysed how women under the auspices of the End Conscription Campaign (ECC) protested against the apartheid government's expectations of the volksmoeder. These women rejected the government's large military budget and militarisation that took the form of deployment of soldiers in war-torn African countries.

Janet Cherry ${ }^{78}$ evaluated how the restrictive laws of the 1980s led to the emergence of the Port Elizabeth Women Organisation (PEWO) and the formation of a UDF women's organisation, much to the dislike of the ANC Women's League, FEDSAW and the ANC itself. Women were by no means passive; they contested for their spaces within such organisations and took radical steps in addressing women's and social issues. "The entire female workforce in the township, most of whom were domestic workers, engaged in a totally successful withdrawal of their labour". ${ }^{79}$ Pat Gibbs, ${ }^{80}$ on the other hand, used women's experience in labour movements to evaluate their agency in trade unionism by means of a case study. ${ }^{81}$ While women faced family breakdown in their shop steward life, they persisted for the sake of recognition of women within Cosatu and on shop floors.

In their respective chapters, Sheila Meintjes, Nthabiseng Motsemme, ${ }^{82}$ Caroline Wanjiku Kihato ${ }^{83}$ and Yvette Abrahams, evaluatd new identities and struggles ranging from the naked women's protest; discourses in the time of HIV/AIDS; immigrant women in Johannesburg; and the re-reading and re-evaluating of the historiography about Sarah Bartman. In a series of interviews, Meintjes argued that the naked women's protest challenged the Urban Areas Act. The women used

76. R. Suttner, "Women in the ANC-led Underground", in Gasa, (ed.), Women in South African History, p 243.

77. Since contributing to Walker's book in 1990, Cock has been promoted to professor in the Sociology Department at Wits and published more books on women in South Africa.

78. An independent researcher and feminist activist based in Port Elizabeth, Cherry is involved in research on women's rights in rural areas and research projects for the HSRC, the TRC, the National Institute for Humanities and the Social Sciences, and has taught at Rhodes University and the Nelson Mandela Metropolitan University.

79. J. Cherry, "We were not Afraid': The Role of Women in the 1980s' Township Uprising in the Eastern Cape", in Gasa (ed.), Women in South African History, p 298.

80. Gibbs focuses on prioritising the voices of the past above the narratives of the present and was a co-writer of two chapters for the first two volumes of SADET, The Road to Democracy in South Africa. See P. Gibbs, "Women, Labour and Resistance: Case Studies from the Port Elizabeth/Uitenhage Area, 1972-94", in Gasa (ed.), Women in South African History, pp 315-343.

81. In the midst of harsh treatment from the state and employers, women from the Kiviet family were shop stewards and contested unfair labour practices such as racial discrimination, low salaries, unfair leave and unfair dismissals of women.

82. At the time, she is working on her PhD on issues of HIV/AIDS, love, intimacy and the politics of survival.

83. At the time of writing she is a policy analyst at the Development Bank of Southern Africa, and editor of Development Southern Africa. 
their bodies to shame the municipal authorities for failing to respond to their needs. ${ }^{84}$ Women forced the authorities to hear their voices and this informed future legislation in South Africa, for example in the formulation of the country's 1996 Constitution.

Motsemme, looking at recent discourses, argued that owing to poverty, women ended up looking for other means of survival, irrespective of their knowledge of the risk of HIV/AIDS. Women at Chesterville resorted to the ukuphanda cult as a survival strategy. They looked for rich or working men to fend for them, and in return, fend for their families, including their parents, who accepted this trend. As Motsemme put it: "There is an unspoken expectation at home that after a night out [with a boyfriend], she must come home with something that contributes to the household economy." 85

Caroline Wanjiku Kihato concluded that women were neither victims nor passive; that they survived social and economic marginalisation, physical harm and traditional oppression, and that they negotiated their space with everyone in whichever way, even if it might be deemed immoral, as with prostitution. These women embodied multiple identities, sometimes using them strategically to their own advantage. ${ }^{86}$ In re-reading and re-evaluating the historiography about Sarah Bartman, Yvette Abrahams rebuked patriarchal and racist narratives that have been based on epistemological biases against Bartman and Khoe history. Abrahams provided a womanist lens to evaluate of the life of Bartman as a personal journey. ${ }^{87}$ While this journey exposed her prejudices, it was enabling to question historians' and authors' motives in outlining the life and presentation of Sarah Bartman.

While some reviewers, notably Van der Spuy and Clowes (see below) took serious exception to the Gasa-edited collection, one cannot deny that this publication was a powerful contribution to follow Walker's volume. Contributors did not aim to position women in the history of South Africa, but they were able to re-write women's history through a woman's lens. They were able to "remove boulders" as the title claims, and show women's agency in every aspect of their lives. This volume was able to close some of the historical gaps in Walker's volume. The contributors to Gasa's volume managed to employ history's conventional methods to unpack women's role in South African history. The chapters by Yvette Abrahams, Helen Bradford and Pumla Gqola to mention but a few, have re-written and revisited past methodologies in explaining the role of women in South African history.

The Gasa collection responded well to Manicom's concern, expressed in her article in the Journal of African History in 1992, and echoed by several reviewers of

84. S. Meintjes, “Naked Women's Protest, July 1990: 'We won't Fuck for Houses'”, in Gasa (ed.), Women in South African History, p 350.

85. N. Motsemme, “Loving in a Time of Hopelessness': On Township Women's Subjectivities in a Time of HIV/AIDS", in Gasa (ed.), Women in South African History, p 391.

86. C. Wanjiku Kihato, "Invisible Lives, Inaudible Voices? The Social Conditions of Migrant Women in Johannesburg", in Gasa (ed.), Women in South African History, p 400.

87. Y. Abrahams, "Ambiguity is my Middle Name: A Research Diary", in Gasa (ed.), Women in South African History, p 421. 
the Walker volume, that "South African feminist historians are white and middle class". ${ }^{8}$ The collection has moved boulders by extending beyond what historians narrowly tended to focus upon. Contributors have moved from addressing social history to engaging in political and state history to conceptualise how women have also contributed to the making of the South African state. Studies that tended to champion men, such as in the context of war and labour, have now addressed the important roles played by women. ${ }^{89}$

\section{Reviews of Women in South African History}

The 2007 publication was not reviewed in nearly as many journals as the Walker collection of some seventeen years before. Karen Bruns, who was with the HSRC, wrote a review of the Gasa edited collection which appeared on the HSRC publishers' press portal. She argued that the book's authors brought different, unique viewpoints to previously unknown women's history. The book, she said “...sets out to showcase women's location, presence and experience in history from different points of view". ${ }^{90}$ In essence, the review acknowledged that previous narratives perpetuated patriarchal views of women's contribution to history, thus ignoring nuances and agency created by women. Bruns argued that because authors ranged from activists to academics, the book provided women's history from all aspects of life, particularly from a feminist perspective.

Ekine Sokari, a freelance writer and researcher, reviewed the Gasa volume in one of the 2007 issues of Pambazuka News, Pan African Voices for Freedom and Justice. She argued that Gasa's compilation presented a fresh, radical feminist approach to women's history that outlined the challenges and dangers women have faced in the past three hundred years. She believed that the book was:

a radical departure from the traditional history texts in that it uses feminist analysis rather than the "more acceptable gender analysis" in its approach, by examining the ways in which gender intersects with race, class and other forms of identity and location in South African history". ${ }^{91}$

According to Sokari, the book challenged uncontested perceptions about women in trade unionism, slavery, mass mobilisation and exposed blatant racist and sexist male, and to some extent, female women's history writing. She mentioned specifically Yvette Abrahams' piece on Sarah Bartman, which took issue with racist historical writing and paucity of sources.

In her review, Teresa Barnes of the University of Western Cape submitted that the Gasa collection was unapologetic in explaining women's history from a feminist

88. Manicom, "Ruling Relations, Rethinking State and Gender, p 442.

89. Manicom, "Ruling Relations, Rethinking Satet and Gender, p 443.

90. K. Bruns, "Review of Women in South African History", HSRC www.pressportal.co.za, p 1, accessed 13 April 2012.

91. E. Sokari, "Review of Women in South African History", http://www.pambazuka. org/en/category/books/40950, accessed on 13 April 2012. 
perspective. She was of the view that the book presented the choices, agency, voices and nuances created by women in the midst of patriarchal domination. ${ }^{92}$ She went on to say that it illuminated and explored traces of resistance, the embodiment of women's agency and contours that defy a single interpretation of women's history. She maintained that authors were able to decode women's action within history as a male dominated discipline. Thus, while women might have been narrating wellknown topics like women in leadership, they also asked questions that recognised women's agency in decision making.

Patricia Van der Spuy and Lindsay Clowes wrote a review in Kronos, the academic journal based at the University of the Western Cape. They interrogate Gasa's edited volume and a book by Helen Scanlon, also published in 2007: Representation and Reality: Portraits of Women's Lives in the Western Cape, 19481976. They were not as complimentary of the Gasa volume as Sokari, Bruns and Barnes. They acknowledged that Gasa's collection was path breaking, but they surmised that because of its political nature, contributors failed to become part of the history process as promised by the editor. These two reviewers questioned the lack of historical self-reflective writing that would have given this volume a nuance not limited by academic and political chains. While citing the chapters by Gqola, Bradford and Abrahams as moving and self-reflective, they questioned the exclusion of and unfair criticism levelled against pioneers like Walker and Wells who, had they been given the chance, might have reflected on their earlier writing as being part of a historical process. As they put it: "There is an apparent scapegoating of two specific historians, Julia Wells and Cherryl Walker, whose work in the 1980s - influenced by contemporary concerns - laid much of the groundwork of the histories of women's militancy in South Africa, and ironically, of this very volume."93

These two reviewers also argued that authors in this volume failed to present their feminist approach and also failed dismally to engage with debates on gender analysis and feminism. In essence, the two reviewers found contradictions between the editor's preamble that called for emancipation, historical process and transdisciplinary methodologies and the actual narratives presented by contributors. They argued that the intensity of the debate proposed by Gasa in her preamble was not reflected accurately in most of the chapters. ${ }^{94}$ Further, they challenged the book's innovativeness and regretted the absence of "fresh authors", who might have brought new perspectives by infusing their personal experiences into their narratives, thereby re-thinking past methodologies.

As indicated above, this collection was not reviewed as widely as the earlier Walker collection. However, the majority of reviewers indicated that the Gasa book was a watershed in South African women's history in that it re-evaluated women's history from a feminist and activist perspective. While some thought that the

92. T. Barnes, "Review of Women in South African History, edited by Nomboniso Gasa", Feminist Africa, 9 (2007), pp 139-142.

93. Van der Spuy and Clowes, "Accidental Feminists?” p 228.

94. Van der Spuy and Clowes, "Accidental Feminists?", p 230. 
collection would not evoke objective analysis on the complexity and multiplicity of women's stance because it was conceptualised by a government department, most reviewers acknowledged that the contributors had transcended that barrier. While Gasa and her fellow contributors made little mention of the Walker volume, Gasa did acknowledge, albeit very briefly, that Walker's work contributed to an understanding of the expression of women's status in South African history.

\section{Comparative reflection: How were these two books received?}

The two collections had two separate agendas. Walker's agenda was to raise an awareness amongst academics of the role women played in the development of southern Africa and its history. Authors attempted to mitigate the scarcity of women's history in mainline historical perceptions and to review what had already been written about women. In this it was successful, although with limitations. It was used as a reference many a time by historians who challenged women's invisibility. It was inherently an academic project.

In Gasa's volume, the agenda was different - to shift borders, to challenge. The fact that the collection was commissioned by the government is indicative of concern about the dearth of women's history. After winning the election in 1994, the ANC government initiated numerous projects to raise an awareness of women's plight and to increase an awareness of their participation and visibility. If initiatives to drive women-orientated initiatives and the representation of women in parliament are unable to shake the fixity of patriarchal perceptions - and if women at that level are merely obliged to toe political lines - then the challenge remains. The agenda of Gasa's collection was to remove these boulders and re-align women's history from the colonial to the contemporary context. The collection succeeded in this regard although it should be noted that to some extent, it did not take full advantage of recent historical research. The approaches in the two publications are very different but then it must be remembered that the two projects were carried out at different times. While Walker's collection is academic in focus, it relied largely on secondary sources rather than original research. Although the same trend was also apparent in Gasa's collection, there are a few authors who were able to use oral history skills to reach their conclusions.

Thus far, this article has outlined the content of the volumes edited by Walker in 1990 and Gasa in 2007, and the response to this work expressed by peer reviewers in scholarly journals after its publication. The fact that the Walker volume has been reviewed far more extensively and that reviews continued to appear several years after the date of publication, compared to the relatively few reviews of the Gasa volume, cannot serve as a sole indicator of the merits of one work above the other. Walker's volume broke new ground and Gasa's book would not have been expected to make as big a wave. Furthermore, scholars tended to allocate their research time to producing subsidy-eligible articles of their own than reviewing books written by their colleagues. Writing book reviews has been relegated to scholarly community service or collegial courtesy in a system which does not recognise reviewing books as a "performance indicator". 
Yet the fact remains, that Walker's collection received far more attention in the way of reviews than Gasa's and the citation history for the Walker volume is also more illustrious. Encouraging for the Gasa volume is to observe that the impact of the Walker collection seems to have increased with age. By mid-June 2015, Google Scholar had registered 274 citations for the 25-year old book Women and Gender in Southern Africa to 1945 and there were 20 citations for the 8-year old Women in South African History. ${ }^{95}$ While the International Bibliography of the Social Sciences (IBSS) revealed no record of the Gasa volume being cited in any of the journals it covers, the Walker volume had been cited in journal articles and dissertations indexed by this bibliography 57 times between 2003 (the year in which the data collection had commenced) and 2014.

Bibliometric data in itself, of course, is neither self-explanatory nor conclusive of any tendencies. As Kousha, Thelwall and Rezaie reminded readers in a study of 2011, influential research can remain uncited and bibliometrical indicators are no replacement for research-quality assessment. ${ }^{96}$ The fact that Walker's volume was referenced many times throughout the world was an affirmation that the project towards the recognition of women's history has reached some maturity. It also indicated that the Walker volume has had an effect on the shaping of historical writing on South Africa by international scholars.

Moving on to another set of information, that on the prevalence of the two books in libraries in South Africa and across the world, it is clear that the Walker volume has circulated far more effectively over the past two and a half decades than the Gasa one over the decade since its appearance. The WorldCat database holds information for 675 copies, 188 of them e-books, of Walker's Women and Gender in libraries worldwide, and 12 hard copies of Gasa's Women in South African History. SACat indicates that 36 South African libraries hold a copy (both electronic and hard format) of the Gasa-edited book. With the HSRC's open access policy, however, the latter can be downloaded from the website of the press free of charge. It is significant that this free access has not translated into intensive citation over the past few years.

With these hard facts in mind, it helps to turn, for perspective, to scholars who are working, writing and teaching in the field. In an interview in 2013, Sheila Meintjes, who has contributed to both volumes, pointed out that Gasa's book was not intended to contest Walker's collection, but to show how women's issues took shape

95. My thanks to University of Pretoria information specialist, Alett Nell for help in obtaining this data. For a discussion on the value of Google Scholar as a source in disciplines such as History, see K. Kousha, M. Thelwall and S. Rezaie, "Assessing the Citation Impact of Books: The Role of Google Books, Google Scholar and Scopus", American Society for Information Science and Technology, (November 2011), p 2157. The authors explain that traditional citation indexes like Web of Science (WoS) and Scopus are article-based and thus not as useful for subject areas such as History, where "books and monographs are one of the mail platforms for research communication".

96. Kousha, Thelwall and Rezaie, "Assessing the Citation Impact of Books", p 2148. 
within different institutions. ${ }^{97}$ It was meant to tell a story, not to give too much information, because it had been aimed at public consumption. On the same topic, also in an interview in 2013, Natasha Erlank concurred. She argued that what Gasa's collection does, which Women and Gender in Southern Africa to 1945 does not do, is to tackle issues that became polemical in the 1990s on the difference between Western style socialist feminism (and what some of the contributors in Gasa's collection termed Western feminism) and "womanism". 98 What is key in the comparison of the two collections is that they were produced in different contexts, with Walker's collection concentrating on the history of gender while Gasa focused on women in history, also women inserting themselves into the future history. In a nutshell, the focus in Gasa's collection was more contemporary and less historical. In 1992, Manicom pointed out that it could not be "assumed that the production of a 'critical mass' of feminist and women's history will prompt a more profound, gendered rethinking of the historical enterprise" ${ }^{99}$

\section{Conclusion}

Walker's and Gasa's volumes stand out as two beacons that have presented women's history with new perspectives as opposed to previous historiographies that ignored women's history. The two volumes also indicated the shift in methodological approaches. They presented a challenge for social historians to rethink the place that women's history has occupied in their perspective. The reviews of both volumes serve as a testimony to their impact and the fact that they have sparked debate in feminist circles. As van der Spuy and Clowes argued, Women in History was not the first comprehensive volume on the history of women, as mistakenly implied in Sokari's review of Gasa's volume. Walker's volume was first, as is evident from the fact that even some of the contributors, including Gasa herself, make reference to it in their work. The continued use and long-term citation record of Walker's volume indicated that women's history has gained some prominence in South African studies internationally, which in turn, reinforced its status in South Africa. It may not have developed as a separate field of study, but the citation evidence, and the reflections of the scholars involved, imply that South African women's history has become more pervasive in various fields of historical scholarship.

The reviews of the two volumes showed that the two books were received differently mainly because of the reviewers' positions. Most of Walker's reviewers were adamant that the contributors did not dwell much on agency and how women contested the situations they faced. The Gasa reviewers, on the other hand, believed that the contributors had gone beyond just rectificatory history; they had explained how women contested the contours of an uneven society. They do not just relate what women did in the past, they show how women challenged patriarchal society. For instance, the collection revisited the position of enslaved women; the plight of women in the HIV/AIDS pandemic; and how women's history had been presented.

97. S. Meintjes, interview conducted by L.F. Ntwape at Wits, 21 August 2013.

98. N. Erlank, interview conducted by L.F. Ntawpe on 10 September 2013, via Skype.

99. Manicom, "Ruling Relations, Rethinking State and Gender", p 443. 
The main difference between these two volumes is that while Walker's volume did not include all racial groups in South Africa, Gasa's attempted to accommodate most racial groups. Moreover, the sources available to Gasa's contributors were more accessible than those available at the time when Walker's was compiled. In terms of similarities, both volumes acknowledged that the contributions are not exhaustive and there is room for further debate on women's history in South Africa. Indian identity, PAC and Inkatha membership, lesbian rights and many other themes were not covered intensively in either volume. Nevertheless, both publications were beacons in the historiography of South African women's history.

Irrespective of the reviews mentioned above, the fact remains that in the late 1980s and early 1990s, there were few black academics in South Africa to contribute to Walker's volume. They were more concerned with the fight against apartheid than looking into the role of women in the liberation struggle. The readings here show that even women in exile were too heavily involved in the struggle to strive for the emancipation of women as individuals. Gasa's volume was testament to the fact that much had changed by 2007 . More black women are academics and live in a politically free South Africa; they have contributed forcefully to the volume.

The fact that Gasa's volume was sanctioned by the post-1994 South Africa, is a clear indication of the growth of women's history in South Africa. The government recognised the need to prioritise women's history. The prominence of academics and male historians in the production of women's history narratives has been dimmed in favour of those complied by activists and feminists who are now taking centre stage in the production of women's history in South Africa.

The two volumes have claimed space for women's history within the public sphere. They have influenced the study of history with various stimulating approaches and have raised new debates. What remains in question is whether and to what extent they have contributed to the shaping and shifting of the categories of women's history, feminist history and gender history in the South African context. In an article published in Rethinking History in 1997, Penelope Corfield summarised the international tendency in women's history as a field "transforming itself - again not without continuing controversy - into the study of historical gender. That shift suggests that the subject has its own internal dynamic as well as sharing in wider changes within the discipline."100 She also emphasised how some historians of women's history began "to analyse the various ways in which members of the 'second sex' had refused to accept their subordinate fate" and suggested that "rather than a story of victimization, women's history could be reinterpreted more positively". 101 This assessment seems applicable to both the Walker and the Gasa book projects. Indeed as early as 1989, Judith Bennett suggested that "the nascent field of women's history provides a new forum for feminist investigations of the past". ${ }^{102}$

100. P.J. Corfield, "History and the Challenge of Gender History", Rethinking History, 1, 3 (1997), p 242.

101. Corfield, "History and the Challenge of Gender History", p 243.

102. Bennett, "Feminism and History", p 251. 
To what extent would Corfield's assertion about women's history's rapid movement "from a fringe interest into a mainstream one",103 be applicable to the South African scene? Our assessment of the Walker and Gasa volumes in this article and the reflections on their influence shared by the scholars who were interviewed and asked for their opinions, confirm that over the past decades, women's agency has been made more visible and that more women have been introduced to a more radical approach of analysing historical data.

It remains to be seen whether women's history has been elevated, institutionalised and prioritised in totality in the South African context, or whether we are still in the throes of this process, which as Gaitskell explained some two decades ago, must precede any possible aspiration towards gender history. ${ }^{104}$ The effectiveness of government initiatives to improve women's position in society since the 1990s had been clouded by political affiliations. It is also doubtful whether the potential released by volumes such as those by Walker and Gasa have been absorbed into the South African History school curricula appropriately. These are avenues inviting further investigation and debate.

\section{REFERENCES}

Abrahams, Y., "Ambiguity is my Middle Name: A Research Diary", in Gasa, N. (ed.), Women in South African History: Basus'iimbokodo, Bawel'imilamho/ They Remove Boulders and Cross Rivers (HSRC Press, Cape Town, 2007).

Barnes, T., "Review of Gasa, N. (ed.), Women in South African History: Basus'imbokodo, Bawel'imilambo/They Remove Boulders and Cross Rivers", in Feminist Africa, 9 (2007).

Beall, J., "Women under Indentured Labour in Colonial Natal, 1886-1911, in Walker, C. (ed.), Women and Gender in Southern Africa to 1945 (David Philip, Cape Town, 1990).

Bennett, J., "Feminism and History", Gender \& History, 1, 3 (1989).

Berger, I., "Generations of Struggle: Trade Unionism and the Roots of Feminism, 1930-1936", in Gasa, N. (ed.), Women in South African History: Basus'iimbokodo, Bawel'imilamho/ They Remove Boulders and Cross Rivers (HSRC Press, Cape Town, 2007).

Bozzoli, B., "Marxism, Feminism and South African Studies", Journal of Southern African Studies 9, 2 (1983).

Bozzoli, B and Delius, P, "Radical History and South African Society", Radical History Review, XLVI-XLVII (1990).

Bruns, K., "Review of Women in South African History". Retrieved June 2012, from http://www.hsrcpress.ac.za/.

103. Corfield, "History and the Challenge of Gender History", p 242.

104. Erlank and Clowes, "Writing and Teaching Gendered History", p 232. 
Burman, S., "Fighting a Two-Pronged Attack: The Changing Legal Status of Women in Cape-Ruled Basotholand, 1872-1884", in Walker, C. (ed.), Women and Gender in Southern Africa to 1945 (David Philip, Cape Town, 1990).

Callinicos, L., "Testimonies and Tansitions: Women Negotiating the Rural and Urban in the Mid-20th century", in Gasa, N. (ed.), Women in South African History: Basus'iimbokodo, Bawel'imilamho/ They Remove Boulders and Cross Rivers (HSRC Press, Cape Town, 2007).

Carruthers, J., "Review of C. Walker (ed.), Women and Gender in Southern Africa to 1945", Kleio, 23 (1991).

Cherry, J., "We are not Afraid: The Role of Women in the 1980s' Township Uprisings in the Eastern Cape", in Gasa, N. (ed.), Women in South African History: Basus'iimbokodo, Bawel'imilamho/ They Remove Boulders and Cross Rivers, (HSRC Press, Cape Town, 2007).

Chisholm, L., "Gender and Deviance in South African Industrial Schools and Reformatories for Girls, 1911- 1934", in Walker, C. (ed.), Women and Gender in Southern Africa to 1945 (David Philip, Cape Town, 1990).

Cock, J., "Domestic Service and Education for Domesticity: The Incorporation of Xhosa Women into Colonial Society", in Walker, C. (ed.), Women and Gender in Southern Africa to 1945 (David Philip, Cape Town, 1990).

Corfield, P.J., "History and the Challenge of Gender History", Rethinking History 1, 3 (1997).

Cornwall, A., Readings in Gender in Africa (Indiana University Press, London, 2005).

Duganzich, G., "She's who Make History: Reviewing the Historical Treatment of Black Women by Four South African Scholars", Historia 44, 1 (1999).

Epprecht, M., "Review of Women and Gender Southern Africa to 1945, edited by Cherryl Walker; and Women of Phokeng: Consciousness, Life Strategy and Migrancy in South Africa, 1900-1993, by B. Bozzoli and M. Natsoe", The International Journal of African Historical Studies 25, 2 (1992).

Erlank, N., and Clowes, L., "Reports on Colloquium Sessions. Session 7: Writing and Teaching Gendered History in Africa in the Twenty-first Century", South African Historical Journal, 50 (2004).

Gaitskell, D., "Devout Christianity? A Century of African Women's Christianity in South Africa", in Walker, C. (ed.), Women and Gender in Southern Africa to 1945 (David Philip, Cape Town, 1990).

Gasa, N., "'Let them Build more Gaols"', in Gasa, N. (ed), Women in South African History: Basus'iimbokodo, Bawel'imilamho/ They Remove Boulders and Cross Rivers (HSRC Press, Cape Town, 2007).

Gasa, N., "Feminisms, Motherisms, Patriaches and Women's Voices in the 1950s", in Gasa, N. (ed), Women in South African History: Basus'iimbokodo, Bawel'imilamho/ They Remove Boulders and Cross Rivers (HSRC Press, Cape Town, 2007).

Gasa, N. (ed), Women in South African History: Basus'iimbokodo, Bawel'imilamho/ They Remove Boulders and Cross Rivers (HSRC Press, Cape Town, 2007).

Gibbs, P., "Women, Labour and Resistance: Case Studies from the Port Elizabeth/Uitenhage Area, 1972-94", in Gasa, N. (ed), Women in South African History: Basus'iimbokodo, Bawel'imilamho/ They Remove Boulders and Cross Rivers (HSRC Press, Cape Town, 2007). 
Gilfillan, L., "Review of Women and Gender in Southern Africa to 1945, edited by C Walker, and, Lives of Courage: Women for a New South Africa, edited by E.H. Russell", Current Writing 2, 1 (1990).

Gqola, P., "Tracing the Elusive Lives of Slave Women in (Slavocratic) South Africa", in N. Gasa (ed), Women in South African History: Basus'iimbokodo, Bawel'imilamho/ They Remove Boulders and Cross Rivers (HSRC Press, Cape Town, 2007).

Korb, A., "Review of Women and Gender in Southern Africa to 1945, edited by C Walker", South African Journal of Cultural History, 5, 1 (1991).

Kousha, K., Thelwall, M., and Rezaie, S., "Assessing the Citation Impact of Books: The Role of Google Books, Google Scholar, and Scopus", Journal of the American Society for Information Science and Technology (November 2011).

Krebs, P.M., "Review of Women and Gender in Southern Africa to 1945, by Cherryl Walker", Victorian Studies", 36, 1 (1992).

Manicom, L., "Ruling Relations, Rethinking State and Gender in South African History", Journal of African History, 33, 3 (1992).

Marks, S., "Review of Women and Gender in Southern Africa to 1945, edited by Cherryl Waker", Agenda, 9 (1991).

Meintjes, S., “Naked Women's Protest, July 1990, We won't Fuck for Houses”, in Gasa, N. (ed.), Women in South African History: Basus'iimbokodo, Bawel'imilamho/ They Remove Boulders and Cross Rivers (HSRC Press, Cape Town, 2007).

Motsemme, N., “Loving in a Time of Hopelessness: On Township Women's Subjectivities in a Time of HIV/AIDS", in Gasa, N. (ed), Women in South African History: Basus'iimbokodo, Bawel'imilamho/ They Remove Boulders and Cross Rivers (HSRC Press, Cape Town, 2007).

Ntwape, L.F., “A Historiography of South African Women's History from c. 1990. A Survey of Monographs, Anthologies and Journal Articles", MA dissertation, University of Pretoria, 2016.

Ojo-Ade, F., "Women and Gender in Southern Africa to 1945, by Cherryl Walker; and Mothers of the Revolution: The War Experiences of Thirty Zimbabwean Women, by I. Staunton", Journal of Modern African Studies, 30, 4 (1992).

Parpart, J.L., "Review of Women and Gender in Southern Africa to 1945, edited by Cheryl Walker", Canadian Journal of African Studies, 28, 2 (1994).

Posel, R., "Review of Women and Gender in Southern Africa to 1945, C. Walker (ed.)", South African Historical Journal, 25, 2 (1990).

Russell, M., "Review of Women and Gender in Southern Africa to 1945, by Cherryl Walker", African Affairs 91, 36 (1992).

Scott, J.W., "Gender: A Useful Category of Historical Analysis", American Historical Association, 91, 5 (December 1986).

Siedman, G., "Review of The Comfort of Home: Prostitution in Colonial Nairobi by Louise White; and Women and Gender in Southern Africa to 1945, edited by Cherryl Walker", Signs, 18, 3 (Spring 1993).

Sokari, E., "Review of Women in South African History", http://www. pambazuka.org/en/category/books/40950 accessed 13 April 2012.

Suttner, R., "Women in the ANC-led Underground", in Gasa, N. (ed.), Women in South African History: Basus'iimbokodo, Bawel'imilamho/ They Remove Boulders and Cross Rivers, (HSRC Press, Cape Town, 2007). 
Sylvester, C., "Review of Women and Gender in Southern Africa to 1945. by Cherryl Walker", Journal of Southern African Studies, 17,1 (1991).

Tosh, J., "What Should Historians Do with Masculinity? Reflections on Nineteenth Century Britain", History Workshop, 38 (1994).

Van der Spuy, P. and Clowes, L., "Accidental Feminists? Recent Histories of South African Women: Representation and Reality", review of Portraits of Women's Lives in the Western Cape 1948-1976, by Helen Scalon; and Women in South African History: Basus'imbokondo, Bawel'imilambo! They Remove Boulders, edited by Nomboniso Gasa", Kronos, 33 (2007).

Van Heyningen, E., "Women and Gender in the South African War, 1899-1902", in Gasa, N. (ed), Women in South African History: Basus'iimbokodo, Bawel'imilamho / They Remove Boulders and Cross Rivers (HSRC Press, Cape Town, 2007).

Walker, C. (ed.), Women and Gender in Southern Africa to 1945 (David Philip, Cape Town, 1990).

Walker, C., Women and Resistance in South Africa (David Philip, Cape Town, 1991).

Wallace, M., "Review of Women and Gender in Southern Africa to 1945, by Cherryl Walker", The International Journal of African Historical Studies, 24, 3 (1991).

Walsh, D., "The Growth of Towns", in Wilson, M. and Thompson, L. (eds), Oxford History of South Africa (Oxford University Press, Oxford, 1971).

Wanjiku Kihato, C., "Invisible Lives, Inaudible Voices: The Social Conditions of Migrant Women in Johannesburg", in Gasa, N. (ed.), Women in South African History: Basus'iimbokodo, Bawel'imilamho/ They Remove Boulders and Cross Rivers (HSRC Press, Cape Town, 2007).

Weir, J., "Chiefly Women and Women's Leadership in Pre-colonial Southern Africa", in Gasa, N., Women in South African History: Basus'iimbokodo, Bawel'imilamho / They Remove Boulders and Cross Rivers (HSRC Press, Cape Town, 2007).

Wells, J., We Now Demand! The History of Women's Resistance to Pass Laws in South Africa, (Wits University Press, Johannesburg, 1993).

Wilson, D., "Review of Women and Gender in Southern Africa to 1945, edited by Cheryl Walker", Journal of the International African Institute, 64, 3 (1994).

Woodard, W., Hayes, P. and G. Minkley, G. (eds), Deep Histories. Gender and Colonialism in Southern Africa (Brill, Leiden, 2002).

Zeleza, P.T., Manufacturing African Studies and Crises (Codersia Publishers, Dakar, 1997). 